\title{
Ships and their timber source as indicators of connections between regions
}

\author{
AOIFE DALY
}

Daly, A. 2019. Ships and their timber source as indicators of connections between regions. AmS-Skrifter 27, 133-143, Stavanger, ISSN 0800-0816, ISBN 978-82-7760-183-0.

The precise dating and determination of the source of timbers in shipwrecks found around the coasts of the North Sea and the Baltic Sea, through dendrochronology allows us to see connections between north and south, east and west throughout the region and to a high chronological precision. In this paper we take a look at results of recent analyses of timber from ships, and timber and barrel cargoes, to try to draw a chronological picture, from the twelfth to seventeenth centuries, of links between regions, through transport in oak ships and trade of timber. Archaeological finds of oak from timber cargos in shipwrecks and fine art objects (painted panels and sculpture) show the extent to which timber was shipped from Hanseatic towns along the southern Baltic coast, to western and north-western Europe.

Aoife Daly, Saxo Institute, University of Copenhagen, Karen Blixens vej 4, DK- 2300 COPENHAGEN, DENMARK.

E-mail: aoife.daly@hum.ku.dk and dendro@dendro.dk

Keywords: dendroprovenance, high-precision chronology, timber trade, timber exploitation

Dendrochronology provides fine-tuned chronological precision and is used for the identification of origin of the timber, making it a highly valuable tool for the study of past timber transport and trade. Timbers are preserved in the roofs and walls of historical buildings, and survive in art and furniture. Studying the remains of the ships that carried cargos between regions give us particular insight into the links between regions and the changes that emerged through time. In the study of northern Europe's timber trade there is a special insight to be gained when a shipwreck is found with its timber cargo still on board. This was the case of the Skjernøysund 3 wreck, in southern Norway. ${ }^{1}$ Dendrochronological dating of timbers from both the ship itself and its timber cargo allowed a rare glimpse of the process of timber trade at the end of the fourteenth century. However, let us first take a wider overview of how dendrochronology of oak in northern Europe can be used to show aspects of the timber trade.

Dendrochronologists across Europe have been accumulating tree-ring data over the last six decades and the dendrochronological dataset for oak for northern Europe is made up of tree-ring measurements of thousands of tree samples, including from living trees, and from where timber survives in preserved historical contexts. So-called 'master chronologies' have been built from these datasets for different regions across Europe, and by comparing the tree-ring series from a timber of unknown date with this network of chronologies, the dating and region of origin of the timber is determined. For example, the volume, extent and duration of the trade in oak from the southern Baltic region to the west over three centuries was demonstrated in the 1980s when chronologies for the Gdansk region proved that oak from artworks had grown in that region. ${ }^{2}$

We can divide the data into the terrestrial and the maritime, and also into material from local and non-local sources for the purposes of identifying the evidence for timber trade, and indeed for refining the methodology by which we use dendrochronology to identify the timber's origin. It is the identification of the local, terrestrial dataset that provides us with the tool for identifying both traded timber for use in construction, furniture, sculpture and panelling and for pinpointing the source of objects and constructions 
that are mobile (barrels, ships and boats, artworks etc.). When we are dealing with the high medieval period the terrestrial versus maritime division is quite straightforward, because, as I will suggest below, the extensive trade of building timber has not yet begun. Whereas from about the mid-fourteenth century onwards, the trade in timber across Northern Europe presents us with the need to interrogate the terrestrial dataset, not just to refine the provenance identification method, but also to identify the usage through time of imported construction timber in the terrestrial structural material.

Questions that can be asked of the material dataset include: when does the building take place using the local timber resource; when does the timber get transported to the building location; and can we suggest the reason for the demand for import of timber? As we are dealing with a bulk commodity, transport logistics are not easy, and as the landscape conditions will have a bearing on the ease to which bulk timber can be transported, we should bear in mind each region and its proximity to large rivers to ease transport at the felling end, and coastal versus inland location of the regions importing the timber.

\section{Local versus non-local timber}

Examples of the problems of determining timber provenance using a dataset where exotic timbers are included have been presented elsewhere. ${ }^{3}$ Currently the author is carrying out an analysis of the terrestrial dataset, on the one hand to refine further the provenance determination methodology, but on the other, to examine the material evidence for the trade in timber over time from region to region, that we know took place. The main aim is to identify the local and imported timbers in the terrestrial dataset. This is done by assessing the region of origin of every single timber in the dataset, through provenance determination through tree-ring analysis. Let us, for example, look at the tree-ring dataset from Denmark, that the author has accumulated over the last two decades. The process involves working through the tree-ring data, tree by tree, checking its tree-ring curve against an extensive Northern European oak tree-ring dataset, including master and site chronologies, and identify whether it is of local or non-local origin. The methodology for this exercise is described in detail elsewhere. ${ }^{4}$ The result of this allowed the division of the data into 'local' or 'non-local'.

Another variable that can be extracted from this extensive dataset is the growth rate of each tree represented, expressed in the form of the average tree-ring width. This concept has been presented before, in the context of the analysis of the 'Mollö Cog. ${ }^{5}$ We assume that trees growing in dense forest will grow in competition, and therefore generally will have a narrower girth (on average narrower rings), while trees in a more open landscape can display, in general, a very broad girth, as they need not compete with neighbouring trees for light. We can take the average growth rate of each tree as a proxy indicator for how densely forested a region was at different times in the past. In terms of the tree growth rate, generally the local oaks tend to be faster grown than the non-local, which can be indicative of a gradual trend towards a more open landscape over time, perhaps necessitating procurement of building timber from abroad.

The results of this analysis of local versus imports are plotted in relation to time (the felling of the trees grouped into centuries) (Fig. 1). The local trees are shown in purple, the non-local in orange. It is clear from the diagram, that the dataset is dominated by local timber and that, while the odd exotic timber appears, even in the twelfth and thirteenth centuries, import of non-locals does not dominate the timber supply until about the mid-fifteenth century.

Another aspect worth considering is the context of the imported timber in the dataset. In the Scottish context the imported oak is found in high-status buildings at sites along the North Sea coastline suggesting that these exotics did not reach the interior. ${ }^{6}$ In the Danish dataset a similar picture is emerging. The large harbour towns tend to be the places where the imported timber appears, such as Aalborg, Aarhus and Copenhagen. It will be an interesting next step, in this context, to look at the urban and rural differences in the tree-ring dataset. So, with this picture of the chronology of timber traded to Denmark in mind, let us take a look at some evidence from the maritime dataset.

\section{Skjernøysund 3}

A shipwreck at Skjernøysund located at the southern coast of Norway, named Skjernøysund 3, was surveyed by the Norwegian Maritime Museum in $2009^{7}$ and later, in 2011, was surveyed and excavated as part of fieldwork training of students at University of Southern Denmark, Maritime Archaeology Program. ${ }^{8}$ It is a clinker-built boat, and the outer planking, the framing timbers and the ceiling planks are all of oak. Among the cargo preserved in the wreck were oak planks. The planks were of two sizes. The larger are 'between $25 \mathrm{~cm}$ and $30 \mathrm{~cm}$ 


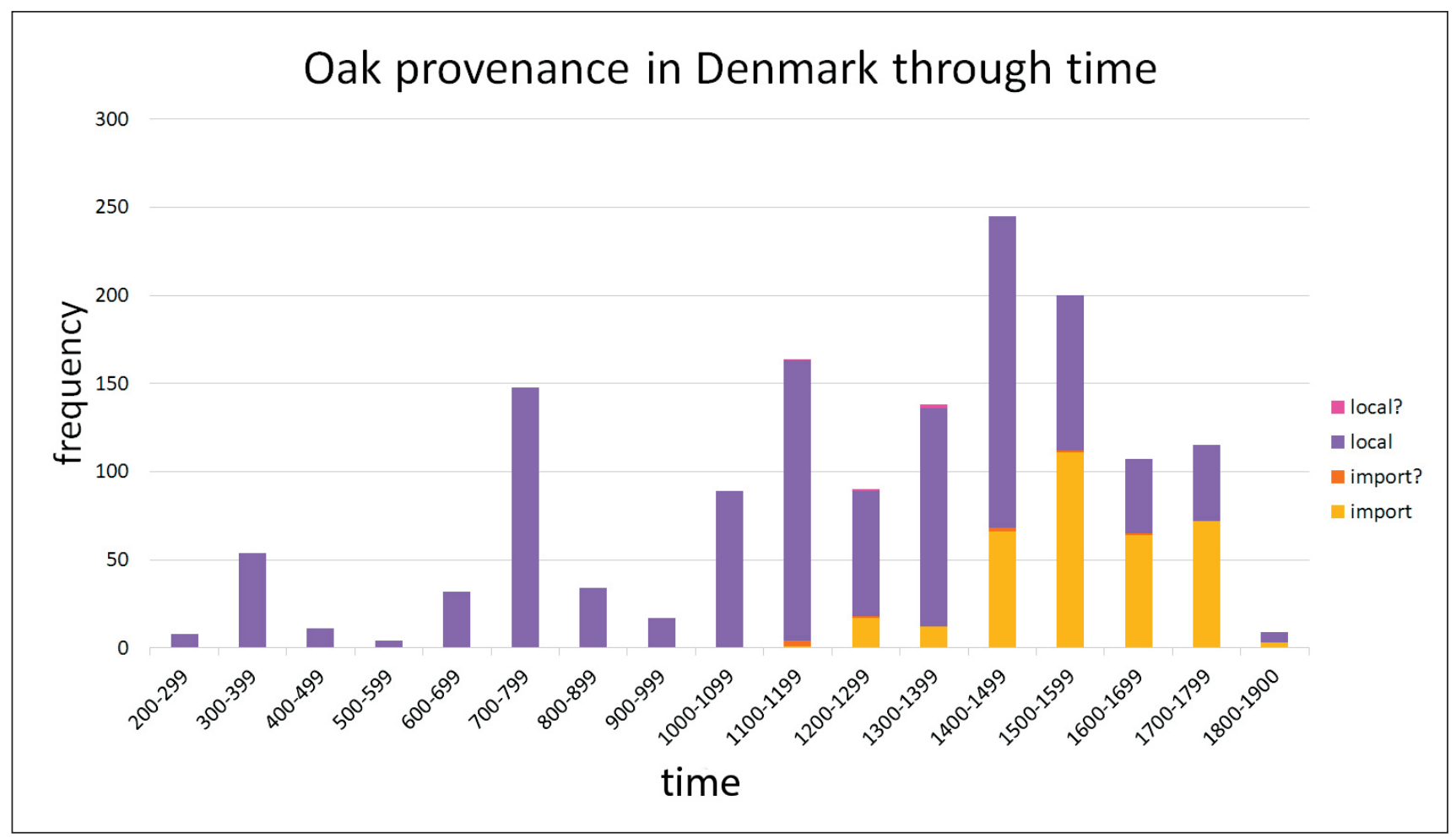

Fig. 1. This diagram summarizes the analysis of the provenance, through dendrochronology, of oak timbers from a terrestrial context in Denmark through time.

and the longest preserved planks are $2.3 \mathrm{~m}$ long' while the smaller are 'up to $16 \mathrm{~cm}$ wide and survive to a length of approximately $50 \mathrm{~cm}$. 9 'These planks are very similar to those found in the Copper wreck, at Gdansk, ${ }^{10}$ and the Skaftö wreck in Sweden ${ }^{11}$ and might be described as wainscots and unfinished barrel staves or clapboards.
Samples for dendrochronological analysis were taken from different components of the Skjernøysund ship and from a range of these cargo planks. ${ }^{12}$ All but one loose timber could be dated, and the result of this is shown in Fig. 2. Bark edge preserved on three of the ship's timbers show that the trees were felled in winter

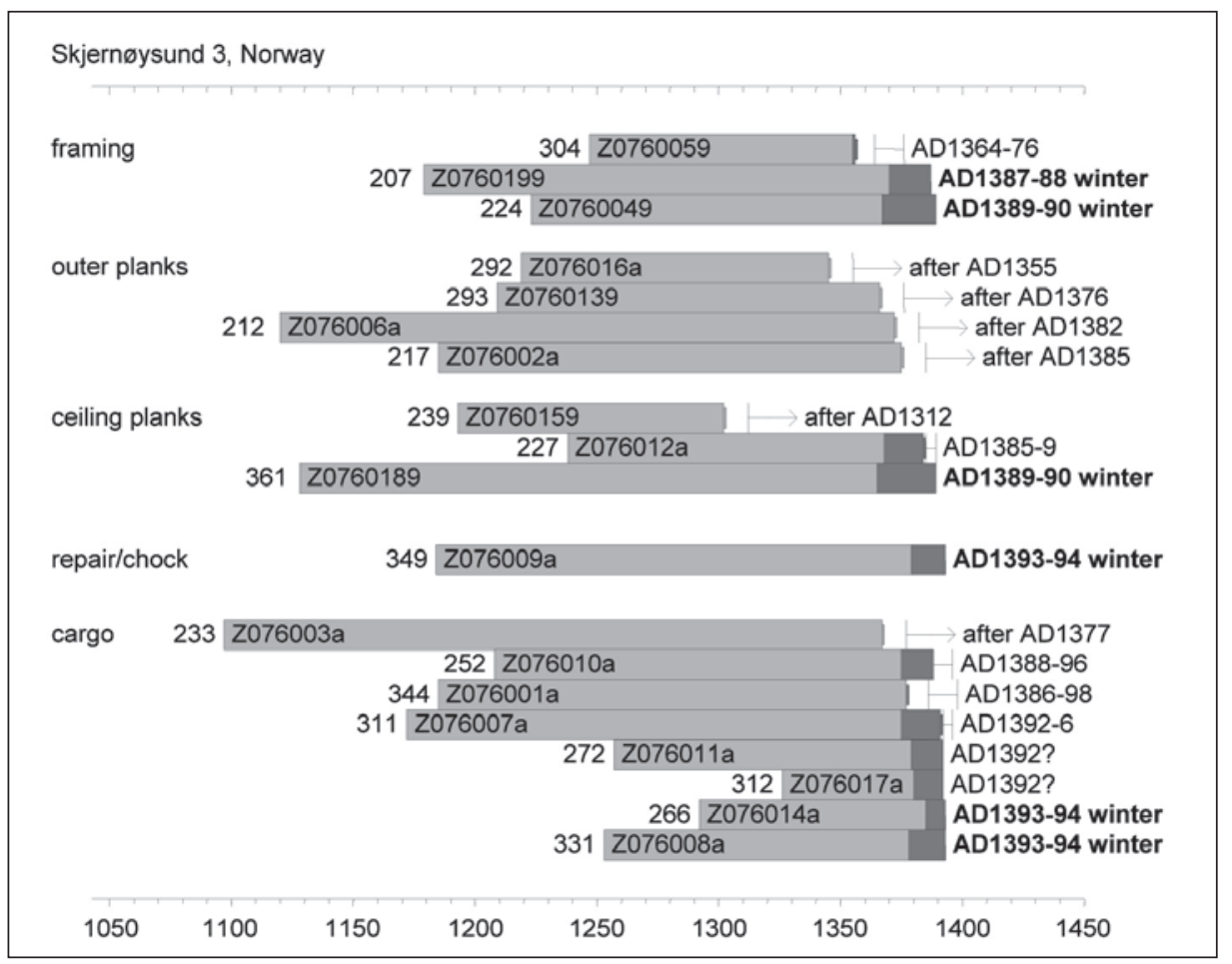

Fig. 2. Diagram showing the results of the dendrochronological dating of ship and timber cargo from Skjernøysund (Skjernøysund 3), Mandal, South Norway. 
$1387-88$ and winter $1389-90$. Two of the cargo planks also had bark edge, showing a felling date of winter 1393-94. If the ship was wrecked the same year that the trees for the cargo were felled, the ship was just four years old when it met its end, on the Norwegian coast.

The correlation between the tree-ring curves from the timbers from the ship and cargo showed no clear distinction between the timber elements, indicating a very similar source for the ship timbers and the cargo. The tree-ring curves are averaged to form a single average chronology of 297 years in length and the analysis shows that the timber is of a southern Baltic origin. The test for the region of origin of the trees is mapped (Fig. 3). The technique for defining the origin of timber through dendrochronology was the subject of the author's doctoral thesis. ${ }^{13}$ Before this, provenance determination was carried out at a wide, regional level, using large so-called master chronologies for oak. The aim of the thesis was to deconstruct these large groups, to refine the precision to which the provenance could be identified. In practice this consists not of deconstruction of the master chronologies, but rather to reconstruct the way in which the data was put together, taking the original single-tree measurements as the starting point. For this the author was very kindly given access to a previously assembled oak tree-ring dataset that a group of laboratories had assembled during the EU funded project 'Climate from Tree-rings' in the 1990s. ${ }^{14}$

The method developed entails testing the provenance of a construction (for example, a ship) at three levels. First, the tree-ring series from the ship timbers are cross-matched and those that show good correlation are averaged to a mean tree-ring curve that represents the ship. If this exercise indicates several timber groups, potentially indicating several geographically discrete timber sources, these are averaged and tested separately. The three-level test then is where the correlation is calculated between the ship average and master chronologies (level 1), site chronologies (averages of tree-ring series within single sites, level 2) and with individual tree-ring series in the dataset (level 3). A detailed description of the technique has been given elsewhere. $^{15}$

In the map shown in Fig. 3, both the first level (blue circles) and second level (green circles) tests are illustrated. Now, while it is clear from the map that the highest correlation, expressed as $t$-values, ${ }^{16}$ are achieved with chronologies for Gdansk and Elblag, at the mouth of the Vistula river, high correlation also appears with tree-ring data from a barrel from Copenhagen, from doors in York Minster, in northern England and from boat planks reused in a revetment in Grimsby, England. ${ }^{17}$ These are all other examples of southern Baltic oak timber in the west. The evidence from the dendrochronological dataset indicates that this oak trade, shipped as plank products, takes place extensively, from the late fourteenth century, as demonstrated by the discovery of timber cargos in ships like the Skjernøysund 3 from 1389-90 and the Copper wreck from the beginning of the fifteenth century. This oak trade is dominated by timber shipped from Gdansk, but the trees can have come from an extensive area e.g. along the Vistula river which flows out into the Baltic Sea at the Bay of Gdansk. Other Hanseatic towns along the southern Baltic coast also took part in this trade.

The Skjernøysund 3 wreck allows us insight into the growing trade of timber that across northern Europe was developing in the fourteenth century. It was dominated by the transport of boards for barrel-making, and planking, probably for furniture, doors, decorative panelling etc. It highlights also the caution that must be taken when we interpret the results of dendrochronological dating and provenance determination of barrels. The origin of the wood is not necessarily indicative of the source of the barrel contents.

The predominance of fourteenth-century ships made of southern Baltic oak is also apparent when we look at the dendrochronological research into cog-type ships. ${ }^{18}$ The use of the historical term 'cog' here in an archaeological context is as defined by Ole Crumlin-Pedersen. ${ }^{19}$ For this ship type we see that the examples dating to the twelfth century are of Danish timber, but in the fourteenth century the Danish finds of this ship type are of southern Baltic timber. As the analysis of the Skjernøysund 3 wreck shows, we see ships of other types made from this southern Baltic oak and this is the predominant source in the fourteenth century. It still remains to assess to what extent these are all ships built in the southern Baltic region, or whether already in the fourteenth century we see ships built elsewhere of transported Baltic oak timbers.

\section{Other wrecks in Norway}

We have seen how both the ship and cargo of the Skjernøysund 3 site are of southern Baltic oak. Let us take a look at the results of dendrochronological analyses of a range of ship finds from Norway, that have been carried out by the author over the last years, and whose 


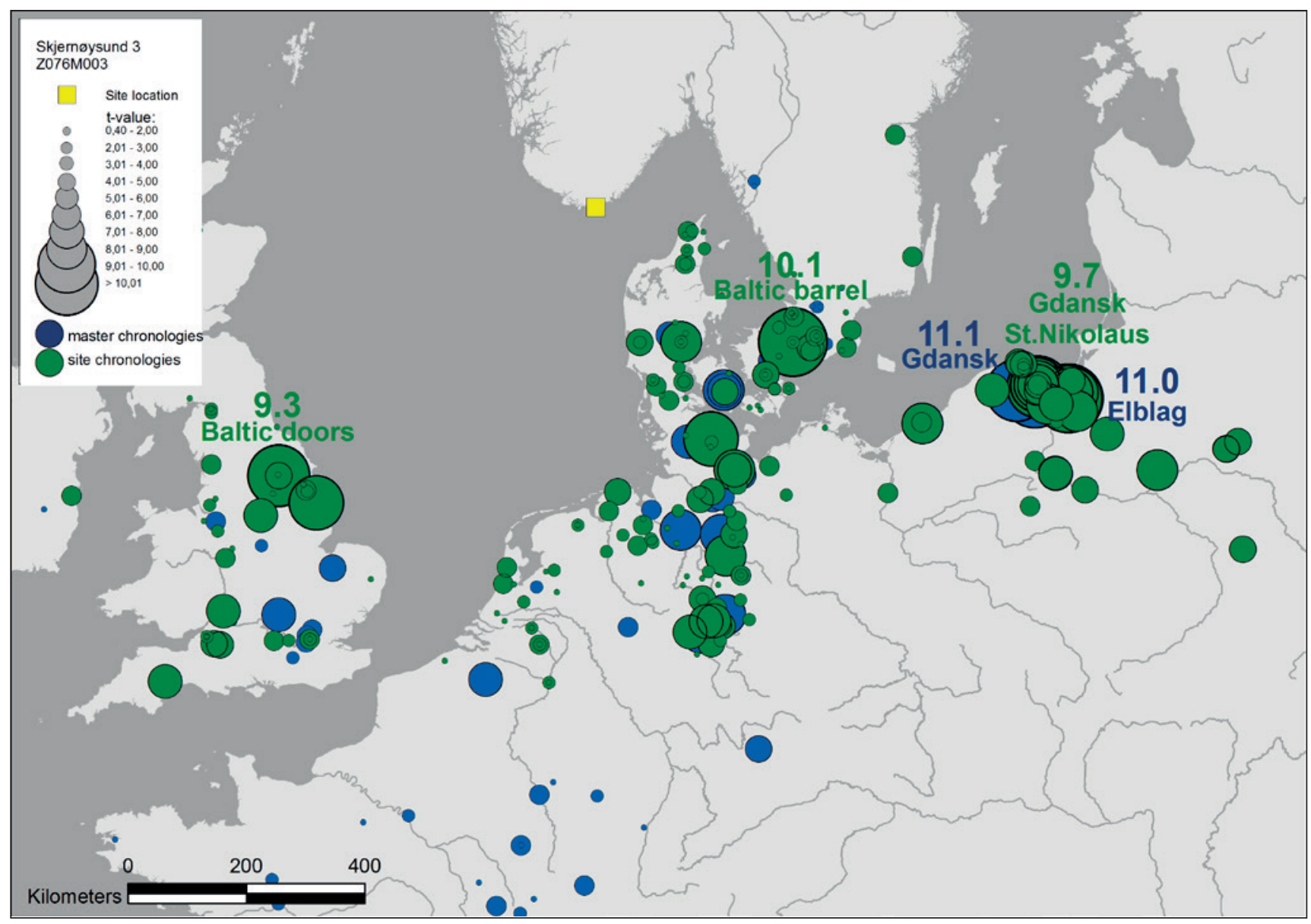

Fig. 3. Map showing the distribution of correlation values when the average tree-ring curve for the ship and cargo timbers from Skjernøysund 3, Mandal, South Norway (winter 1393-94), is compared with a suite of site and master chronologies for Northern Europe - site chronologies shown in green, master chronologies in blue.

dating falls in the period of the fourteenth to nineteenth centuries. The dating of the individual tree-ring series of each oak timber from Norwegian ships are plotted (Fig. 4) and the indication of their provenance is given using colour. The dominance of ships of southern Baltic timber in the fourteenth century is clear, with the Avaldsnes ship and the Bøle ship adding to the list. In subsequent centuries a dominance of Scandinavian timber is the rule. Let us take a look at an example from the sixteenth century.

During excavations at the Barcode site, in central Oslo, fourteen ships were found and excavated. ${ }^{20}$ Dendrochronological analysis of these was carried out by the author over several years, as the Norwegian Maritime Museum finished fully drawing and recording each ship timber. The boat called $\mathrm{BC} 14$ has been chosen for presentation here. Four planks, the keelson and the keel are dated from the boat. The tree-ring curves from two of the planks are so similar to each other that these two planks are probably made from the same tree. So three trees are represented in the average curve for the planks from the boat. The boat is built of timbers felled around $1574 .{ }^{21}$ The correlation between the $\mathrm{BC} 14$ average tree-ring curve and a wide network of site and master chronologies for northern Europe is plotted to determine the timber provenance (Fig. 5).

We must bear in mind the fact that the terrestrial tree-ring dataset consists both of local timber and of imports when we are analysing the provenance of a ship from the sixteenth century. As can be seen in Fig. 5, high correlations appear between the BC14 ship from Oslo and a range of chronologies in southern Scandinavia, made from oak timbers found at various historical and archaeological sites. The reason for the spread of high correlation throughout the region in the analysis, instead of the analysis showing a clear indication of the ship's timber provenance, is most probably due to the transported and traded timber throughout the region in the period in question, as demonstrated above (see Fig. 1). A table showing these results in list form sheds further light on the results (Table 1). The 


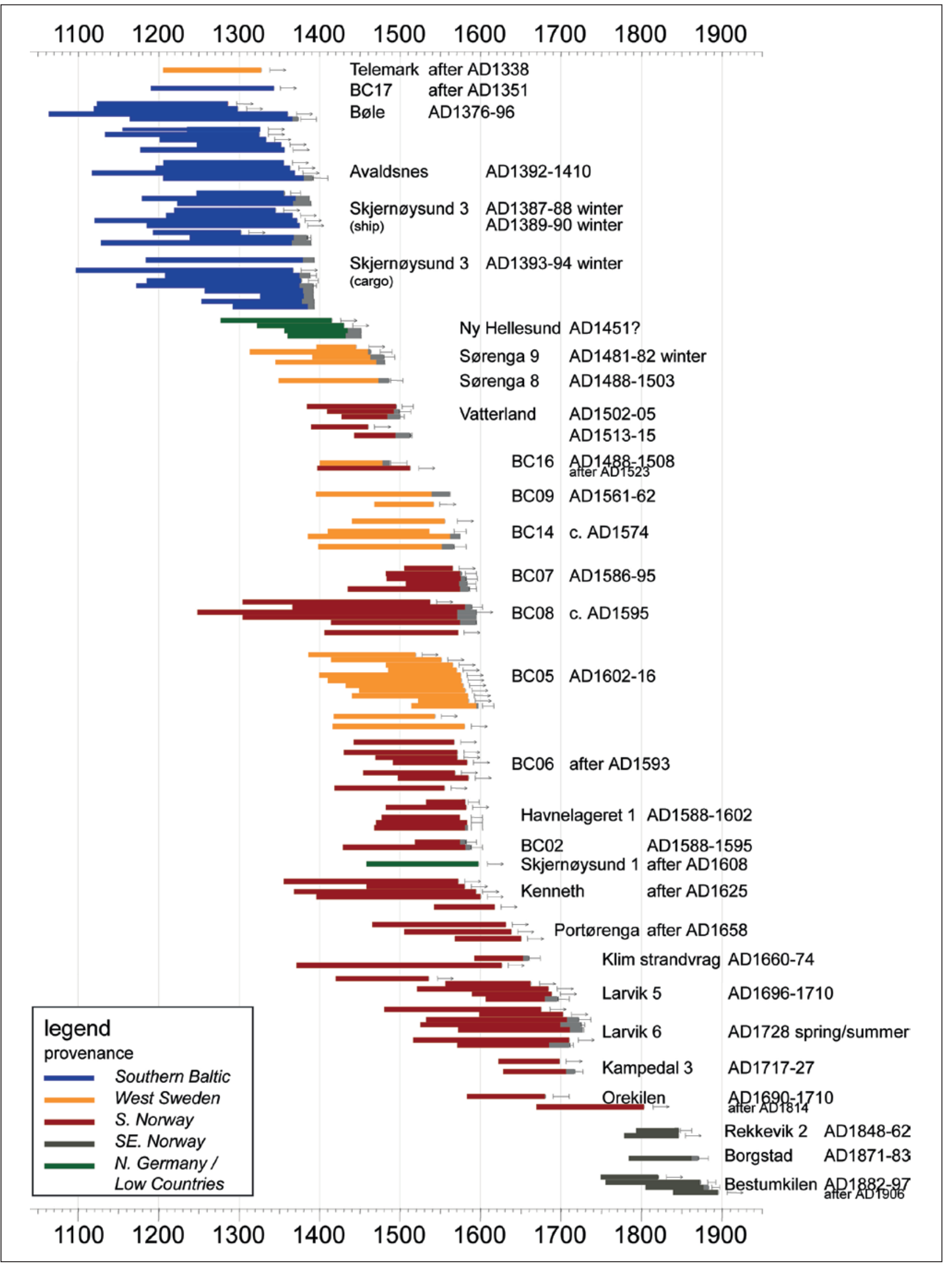

Fig. 4. Diagram showing the chronological distribution of a range of ship or boat timbers (oak) recently dated from Norway - shaded according to the timber provenance. 


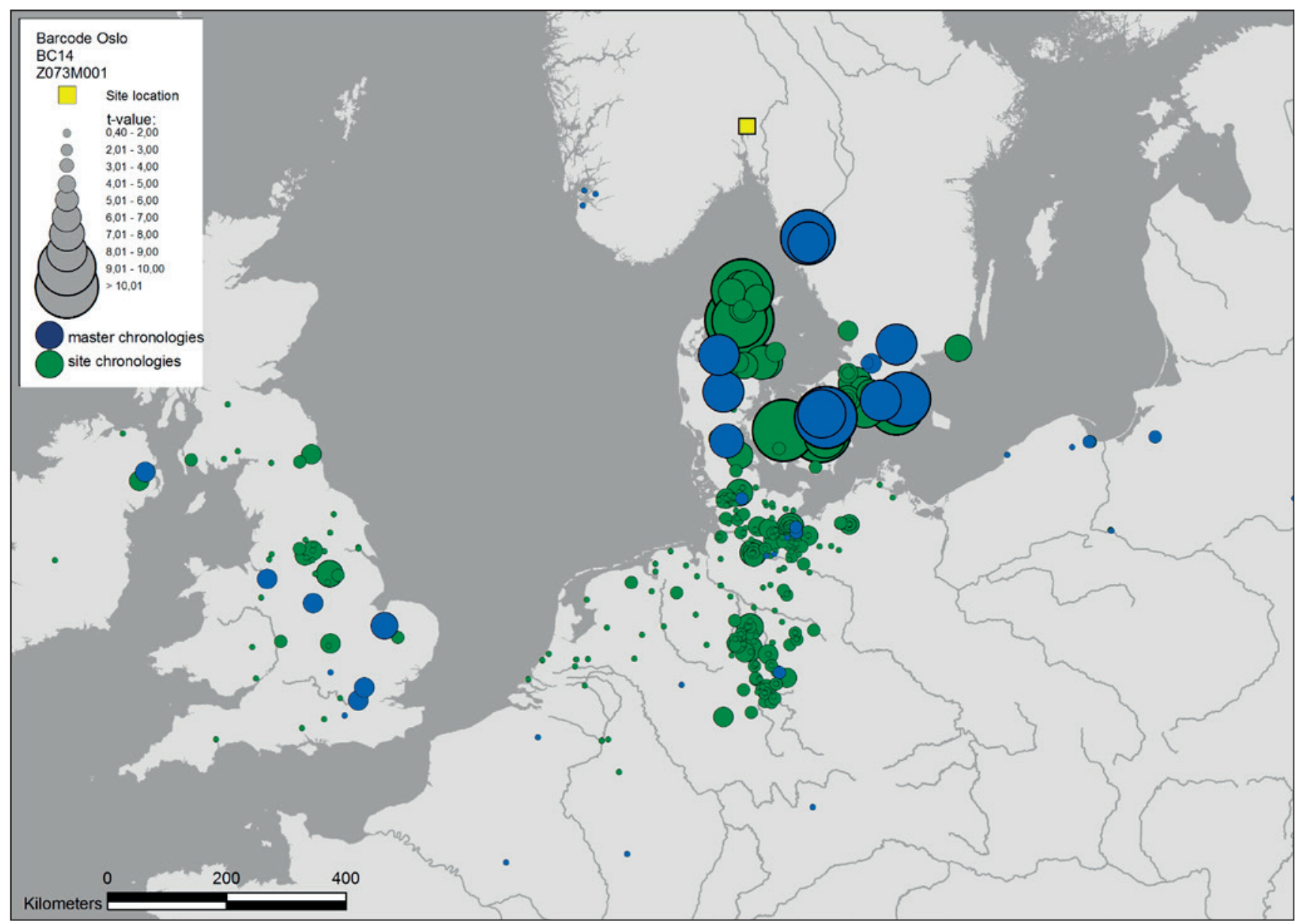

Fig. 5. Map showing the distribution of correlation values when the average tree-ring curve for the Boat BC14 (c. 1574) from Barcode in Oslo is compared with a suite of site and master chronologies for Northern Europe - site chronologies shown in green, master chronologies in blue.

correlation ( $t$-value) between two of the Barcode ships (BC14 again and $\mathrm{BC} 08$ for comparison) and a range of chronologies is listed. At first glance, it is clear that the two ships are made from timbers of very different sources. BC14 not only achieves high correlation with southern Scandinavian chronologies, it also achieves these with tree-ring data from a range of shipwrecks from the fifteenth, sixteenth and seventeenth centuries, that are shown by dendrochronology to be of western Swedish timber, and also from data from several sixteenth-century building phases of Stirling castle in Scotland constructed of southern Scandinavian oak. The other ship from the Barcode site, BC08, in contrast, matches best the tree-ring data from wood we know is from southern Norway. Five oak samples from that boat were analysed and all five are dated. Three had sapwood preserved and the felling of the timbers for the boat took place in about $1595 .{ }^{22}$ As can be seen in Table 1, high correlation appears between the average for the BC08 boat and a range of datasets from Scotland, that are not Scottish oak, but represent the importation of Norwegian oak to Scotland in the sixteenth century. ${ }^{23}$ It also gains high correlation with a range of sixteenth-, seventeenth- and eighteenthcentury shipwrecks that are made from oak from southern Norway.

\section{Discussion}

The above examples serve to demonstrate on the one hand the methodology for determining not just the dating of timber constructions from archaeological and historic sites, but also the origin of the timber. On the other hand, it also underlines the complexity of the tree-ring dataset, which functions both as a tool for analysis of new finds and as the material evidence for trade in timber. The material evidence supplements the evidence from historical sources (such as the Danish sound toll records ${ }^{24}$ ) as it can fill gaps (both chronological and regional) in the historical records, while at the same time shedding light on the transport of timber that did not pass the Øresund. A particularly 
Table 1. Result of the correlation between the average tree-ring curves for two ships from Barcode, Oslo - BC08 (c. 1595) and BC14 (c. 1574) and diverse site and master chronologies. The grey shading highlights the high values. The source of the chronologies is given.

\begin{tabular}{|c|c|c|c|c|}
\hline & - & - & $\begin{array}{c}\text { Barcode ship } \\
08 \text { (BC08) } \\
\text { Z071M004 }\end{array}$ & $\begin{array}{c}\text { Barcode ship } \\
14 \text { (BC14) } \\
\text { Z073M001 }\end{array}$ \\
\hline & start & dates & AD 1304 & AD 1385 \\
\hline & dates & end & AD 1595 & AD 1574 \\
\hline \multicolumn{5}{|l|}{ Scottish imports from S. Scandinavia } \\
\hline Stirling Castle phase 4 (1592) (Crone pers comm 2008) & AD 1390 & AD 1592 & 4.46 & 11.29 \\
\hline Stirling Castle phase 3 (1539) (Crone pers comm 2008) & AD 1361 & AD 1539 & - & 10.26 \\
\hline Stirling Castle phase 3 (1538-9) (Crone pers comm 2008) & AD 1366 & AD 1538 & 3.50 & 9.22 \\
\hline Stirling Castle phase 2 (1505) (Crone pers comm 2008) & AD 1355 & AD 1505 & - & 8.41 \\
\hline \multicolumn{5}{|l|}{ W Sweden ships } \\
\hline Gåsehage boat, Randers (Daly unpublished) & AD 1386 & AD 1567 & 4.92 & 10.60 \\
\hline Copenhagen B\&W wreck 2 (Daly unpublished) & AD 1405 & AD 1607 & 4.04 & 8.48 \\
\hline Sørenga boat 9 , Oslo (Daly unpublished) & AD 1313 & AD 1481 & - & 7.32 \\
\hline Oslo Barcode ship BC09 (Daly unpublished) & AD 1395 & AD 1561 & 4.24 & 6.40 \\
\hline \multicolumn{5}{|l|}{ SW Sweden/Danish ships } \\
\hline Amager Strand Vrag (Daly unpublished) & AD 1313 & AD 1567 & - & 5.83 \\
\hline \multicolumn{5}{|l|}{ Danish chronologies } \\
\hline Astrup Church (Daly unpublished) & AD 1350 & AD 1480 & - & 10.13 \\
\hline Helsingør (National Museum of Denmark) & AD 1345 & AD 1538 & 3.06 & 9.85 \\
\hline Næstved Suså (Daly unpublished) & AD 1052 & AD 1596 & - & 9.69 \\
\hline Ålborg østerå+boulevarden (Daly unpublished) & AD 846 & AD 1771 & 3.28 & 8.80 \\
\hline Mid Jutland (Christensen pers comm) & AD 536 & AD 1980 & 5.49 & 8.55 \\
\hline $\begin{array}{l}\text { Churches in Vendsyssel W Swedish group (Daly } \\
\text { unpublished) }\end{array}$ & AD 1350 & AD 1480 & 3.63 & 8.53 \\
\hline Nyborg Castle Renaissance phase (Daly 2007a) & AD 1310 & AD 1546 & 3.62 & 7.78 \\
\hline Hammer K. (Daly unpublished) & AD 1316 & AD 1514 & - & 6.91 \\
\hline Jylland/Fyn (National Museum of Denmark) & $109 \mathrm{BC}$ & AD 1986 & 3.17 & 6.39 \\
\hline Copenhagen Admiralgade (Daly unpublished) & AD 1347 & AD 1484 & - & 5.87 \\
\hline Copenhagen B\&W bolværk etc (Daly unpublished) & AD 1305 & AD 1743 & 6.28 & 4.70 \\
\hline Churches in Vendsyssel DK group (Daly unpublished) & AD 1009 & AD 1466 & - & 5.73 \\
\hline Funder church late phase (Daly unpublished) & AD 1450 & AD 1660 & 5.77 & 6.64 \\
\hline \multicolumn{5}{|l|}{ Swedish chronologies } \\
\hline West Sweden (Bråthen 1982) & AD 1125 & AD 1720 & 3.80 & 8.91 \\
\hline Ystad SW Sweden (Bartholin pers comm) & AD 1310 & AD 1539 & 4.19 & 8.61 \\
\hline Skåne Blekinge (Bartholin pers comm) & AD 1274 & AD 1974 & - & 6.95 \\
\hline \multicolumn{5}{|l|}{ Norwegian ships } \\
\hline Larvik boats $5 \& 6$ Norway (Daly unpublished) & AD 1480 & AD 1727 & 5.11 & - \\
\hline Copenhagen B\&W vrag 1 nordic (Daly 2007a) & AD 1352 & AD 1568 & 6.42 & 3.65 \\
\hline Oslo Bjørvika 'Kenneth' (Daly unpublished) & AD 1355 & AD 1617 & 7.58 & 4.65 \\
\hline Oslo Vaterland I (Daly unpublished) & AD 1384 & AD 1512 & 8.09 & 5.31 \\
\hline Denmark Klim Strandvraget (Daly unpublished) & AD 1371 & AD 1659 & 9.40 & 4.59 \\
\hline \multicolumn{5}{|l|}{ Scottish imports from Norway } \\
\hline Advocates Close Scotland (Crone pers comm) & AD 1428 & AD 1590 & 6.70 & - \\
\hline Fenton Tower Scotland (Crone pers comm) & AD 1318 & AD 1572 & 7.87 & 6.48 \\
\hline Edinburgh Castle Scotland (Crone and Gallagher 2008) & AD 1358 & AD 1509 & 8.73 & 6.44 \\
\hline Carnock Scotland (Crone 2011) & AD 1317 & AD 1588 & 8.99 & 4.02 \\
\hline Duntarvi Scotland (Crone pers comm) & AD 1385 & AD 1529 & 9.79 & 3.47 \\
\hline
\end{tabular}


clear example of this is seen in the dendrochronology research taking place in Scotland. ${ }^{25}$ The growth in the volume of tree-ring data for oak for Norway in the last years is developing new insight into the extent of the trade in this commodity. Recent research through an international consortium of dendrochronologists under the umbrella of the project 'A Digital Collaboratory for Cultural Dendrochronology (DCCD)' has facilitated the pooling of tree-ring data from across northern Europe, for perpetual archiving, and further research. ${ }^{26}$ The tree-ring data from ship finds in Norway generated by the author and summarized here has been submitted to this collaboration, and this has enabled the identification of Norwegian oak exports in the Dutch and northern German tree-ring datasets. This work is on-going, and will be analysed further, to identify in which context the Norwegian oak is utilized, and of course to compare it to the evidence for oak imported to these regions from other sources. The next task in this context is to analyse the balance between the well documented so-called Baltic timber that we see used particularly for furniture and painting panels on the one hand, ${ }^{27}$ and the trade of timber from other sources and not least the use of native timber throughout the region on the other.

It is demonstrated above that additional details can be attained from the tree-ring dataset, using the example of the trees' growth rate as a potential indicator of forest density. In the analysis of the Danish dataset illustrated in Fig. 1 the imported wood tends to be of slower grown oak than the local from the mid-fourteenth century onwards. When we take into consideration the logistical problems that the transport of bulk timber presents, coupled with the indications that the local tree cover might have been dwindling, it is tempting to suggest that timber availability is a key factor influencing the increase of the import of timber from abroad. If the growth in timber trade across northern Europe is influenced by shortage in the region which imports the timber, then this model cannot be seen to apply in the context of trade of timber into Norway, which had abundant native supply. Neither can we assume that the presence of the southern Baltic timber cargo in the Skjernøysund 3 ship was destined for a Norwegian market, even though the ship was wrecked on the Norwegian coast. The evidence from the Bøle and Avaldsnes wrecks (mentioned above), made of southern Baltic timber, attests to traffic between Norway and the Baltic, but of course these ships could have been built in the Baltic, and are not evidence of timber trade to Norway.
As the two provenance determination maps illustrated here show, we are presented with problems when using the historical, terrestrial dataset. Transported timber in both examples are clearly a factor, and while it is clear in the fourteenth-century example (Skjernøysund 3) with southern Baltic timbers in the west, the sixteenth-century example (Barcode 14) is more problematic, as it seems timber has been extensively transported through the southern Scandinavian region, making a detailed, precise provenance determination of the $\mathrm{BC} 14$ boat more difficult. The process of identifying and isolating the local versus the imported material in the terrestrial dataset that has begun (see Fig. 1) will move towards rectifying this in the future.

Finally, it will be a very useful step to interrogate the historical timber in terms of timber origin (local or import) versus building context. What construction types are built of local timber, and which of imported timber? Is there a divide in terms of urban versus rural, inland versus coastal or in building status - from cottage to castle? This will give us yet another dimension in interpreting this extensive material.

We are privileged in northern Europe when identifying oak timber origin in that there is a very dense distribution, both geographically and chronologically, of sites where timbers are found and analysis is available. At the same time, there are gaps in this dataset that need to be addressed. Further work on the northern European tree-ring dataset holds the potential for many new discoveries.

\section{Acknowledgements}

Firstly I would like to thank the many and varied archaeologists that have entrusted their samples to me for analysis. Secondly, thanks go to my colleagues in dendrochronology for sharing their tree-ring data and thereby allowing me to carry out my research. Some of the analysis presented here was prepared as a component of my project 'Chronology, Culture and Archaeology' generously funded through a European Commission Marie Curie Intra-European Fellowships for career development (IEF) hosted at the School of Archaeology, University College Dublin (June 2011-June 2013). The author has also received funding from the European Research Council (ERC) under the European Union's Horizon 2020 research and innovation programme (grant agreement No. 677152), based at University of Copenhagen. 


\section{Endnotes}

${ }^{1}$ Auer and Maarleveld 2013.

${ }^{2}$ Baillie et al. 1985; Eckstein et al. 1986; Wazny 2002.

${ }^{3}$ Daly 2007a; Daly and Nymoen 2008.

${ }^{4}$ Daly 2007a.

${ }^{5}$ von Arbin and Daly 2012.

${ }^{6}$ Daly 2007a, 217.

${ }^{7}$ Johannessen 2009.

${ }^{8}$ Auer and Maarleveld 2013.

${ }^{9}$ Ibid., 27.

${ }^{10}$ Litwin 1985.

${ }^{11}$ von Arbin 2012

${ }^{12}$ Daly 2011b.

${ }^{13}$ Daly 2007a.

${ }^{14}$ Kelly et al. 2002; Leuschner et al. 2002; Spurk et al. 2002.

${ }^{15}$ Daly 2007a; Daly 2007b.

${ }^{16}$ Baillie and Pilcher 1973.

${ }^{17}$ Tyers pers. comm; Daly and Nymoen 2008, 166.

${ }^{18}$ Daly 2007a; Daly 2009.

${ }^{19}$ Crumlin-Pedersen 2000.

${ }^{20}$ Gundersen 2012.

${ }^{21}$ Daly 2011a.

${ }^{22}$ Ibid.

${ }^{23}$ See e.g. Crone and Mills 2012.

${ }^{24}$ See e.g. Gøbel 2010 or Scheltjens and Veluwenkamp 2012

${ }^{25}$ Crone 2008; Crone and Mills 2012.

${ }^{26}$ Jansma et al. 2012.

${ }^{27}$ Bonde et al. 1997; Daly 2007a; Ważny and Eckstein 1987; Ważny 2002; Daly and Läänelaid 2012; Klein 2005; Hillam and Tyers 1995.

\section{References}

von Arbin, S. 2012. A 15th-century bulk-carrier wrecked off Skaftö, Western Sweden, in N. Günsenin (ed.), Between Continents. Proceedings of the 12th International Symposium on Boat and Ship Archaeology, 67-74. Istanbul: Ege Yayınları.

von Arbin, S. and Daly, A. 2012. The Mollö Cog re-examined and re-evaluated. International Journal of Nautical Archaeology 41(2), 372-389.

Auer, J. and Maarleveld, T. 2013. Skjernøysund Wreck 3 Fieldwork Report 2011. Esbjerg Maritime Archaeology Reports 5. Esbjerg: University of Southern Denmark.

Baillie, M. G. L., Hillam, J., Briffa, K. R. and Brown, D. M. 1985. Re-Dating the English Art-Historical Tree-Ring Chronologies. Nature 315, 317-319.

Baillie, M. G. L. and Pilcher, J. R. 1973. A simple crossdating program for tree-ring research. Tree-Ring Bulletin 33, 7-14.

Bonde, N., Tyers, I. and Ważny, T. 1997. Where does the timber come from? Dendrochronological evidence of timber trade in Northern Europe, in A. Sinclair, E. Slater and J. Gowlett (eds), Archaeological Sciences 1995, 201-204. Oxford: Oxbow books.

Bråthen, A. 1982. Dendrokronologisk serie från västra Sverige 813-1975. Rapport Riksantikvarieämbetet och Statens historiska museer 1982(1). Stockholm.

Crone, B. A. 2008. Dendrochronological analysis of the oak and pine timbers. Stirling Castle Palace. Archaeological and historical research 2004-2008. Edinburgh: Historic Scotland.

Crone, B. A. 2011. Carnock House, Stirling. Dendrochronological analysis of the painted oak beams. Unpublished AOC Archaeology Group report.

Crone, B. A. and Gallagher, D. 2008. The medieval roof over the Great Hall in Edinburgh Castle. Medieval Archaeology 52(1), 231-260.

Crone, A. and Mills, C. M. 2012. Timber in Scottish buildings, 1450-1800: a dendrochronological perspective. Proceedings of the Society of Antiquities of Scottland 142, 329-369.

Crumlin-Pedersen, O. 2000. To be or not to be a cog. International Journal of Nautical Archaeology 29(2), $230-246$.

Daly, A. 2007a. Timber, Trade and Tree-rings. A dendrochronological analysis of structural oak timber in Northern Europe, c. AD 1000 to c. AD 1650. PhD thesis, University of Southern Denmark.

Daly, A. 2007b. The Karschau Ship, Schleswig-Holstein: Dendrochronological Results and Timber Provenance. International Journal of Nautical Archaeology 36(1), $155-166$.

Daly, A. 2009. The chronology of cogs and their timber origin, in R. Bockius (ed.), Between the Seas. Transfer and Exchange in Nautical Technology, 237-248. Proceedings of the eleventh International Symposium on Boat and Ship Archaeology, Mainz 2006. Mainz: RGZM Verlag.

Daly, A. 2011a. Barcode vrag 5, vrag 8 og vrag 14, Oslo. Dendro.dk unpublished report 2011:24.

Daly, A. 2011b. Dendrochronological analysis of oak from a shipwreck, Skjernøysund 3, Mandal, Norway. Chronology, Culture and Archaeology report 2, University College Dublin (unpublished).

Daly, A. and Läänelaid, A. 2012. The dendrochronological dating of three paintings in the style of Bosch/ Bruegel, in E. Hermens (ed.) On the Trail of Bosch and Bruegel: Four Paintings under Magnification, 47-55. Copenhagen: Archetype Publications.

Daly, A. and Nymoen, P. 2008. The Bøle Ship, Skien, Norway - Research history, dendrochronology and provenance. International Journal of Nautical Archaeology 37(1), 153-170.

Eckstein, D., Ważny, T., Bauch, J. and Klein, P. 1986. New evidence for the dendrochronological dating of Netherlandish paintings. Nature 320, 465-466.

Gundersen. J. 2012. Barcode Project: Fifteen Nordic Clinker-Built Boats from the 16th and 17th Centuries in the City Centre of Oslo, Norway, in N. Günsenin (ed.), Between Continents. Proceedings of the 12th International Symposium on Boat and Ship Archaeology, 75-80. Istanbul: Ege Yayınları.

Gøbel, E. 2010. The Sound Toll Registers Online Project, 1497-1857. International Journal of Maritime History 22(2), 305-324.

Hillam, J. and Tyers, I. 1995. Reliability and repeatability in dendrochronological analysis: tests using the Fletcher archive of panel-painting data. Archaeometry 37, 395-405.

Jansma, E., van Lanen, R. J., Brewer, P. W. and Kramer, R. 2012. The DCCD: a digital data infrastructure for 
tree-ring research. Dendrochronologia 30(4), 249-251. Johannessen, J. 2009. Statusrapport 1.2 Kulturmiljø Skjernøysund. Arkeologiske undersøkelser ved Skjernøysund, Mandal kommune, Vest Agder fylke. Unpublished report.

Kelly, P. M., Leuschner, H. H., Briffa, K. R. and Harris, I. C. 2002. The climatic interpretation of pan-European signature years in oak ring-width series. Holocene 12(6), 689-694.

Klein, P. 2005. The use of wood in Rembrandt's workshop. Wood identification and dendrochronological analyses, in M. van den Doel, E. van de Wetering, N. van Eck and G. Korevaa (eds), The Learned Eye. Regarding Art, Theory and the Artist's Reputation, 28-37. Amsterdam: Amsterdam University Press.

Leuschner, H. H., Sass-Klaassen, U., Jansma, E., Baillie, M. G. L. and Spurk, M. 2002. Subfossil European bog oaks: population dynamics as indicators of changes in the Holocene hydro-regime and climate. Holocene 12(6), 695-706.
Litwin, J. 1985. The Copper ship of Gdansk bay: recent discoveries from the wreck, cargo and site, in J. Haarmann and J. Bracker (eds), 5th International Congress of Maritime Museums Proceedings 1984, 42-49. Hamburg: Herman Kampen.

Scheltjens, W. F. Y. and Veluwenkamp, J. W. 2012. The Sound Toll Registers Online: Introduction and First Research Examples. International Journal of Maritime History 24(1), 301-330.

Spurk, M., Leuschner, H. H., Baillie, M. G. L., Briffa, K. R. and Friedrich, M. 2002. Depositional frequency of German subfossil oaks: climatically and nonclimatically induced fluctuations in the Holocene. Holocene 12(6), 707-715.

Ważny, T. and Eckstein, D. 1987. Der Holzhandel von Danzig/Gdansk - Geschichte, Umfang und Reichweite. Holz als Roh- und Werkstoff 45, 509-513.

Ważny, T. 2002. Baltic timber in Western Europe - an exciting dendrochronological question. Dendrochronologia 20(3), 313-320. 